\title{
TECHNICAL AND ECONOMIC VIABILITY OF COFFEE PROCESSING IN DIFFERENT SIZE CLASSIFICATIONS
}

\author{
Igor Luís de Oliveira ${ }^{1}$, Kleso Silva Franco Júnior ${ }^{2}$, Giselle Prado Brigante ${ }^{3}$ \\ ${ }^{1}$ Estudante de Engenharia Agronômica, CESEP- Centro Superior de Ensino e Pesquisa de Machado MG, \\ Avenida Dr Athaide Pereira de Souza, S/N, Machado MG 37750-000 \\ ${ }^{2}$ Professor Dr. do curso de agronomia do CESEP, Centro Superior de Ensino e Pesquisa de Machado MG, \\ Avenida Dr Athaide Pereira de Souza, S/N, Machado MG 37750-000 \\ ${ }^{2}$ Professora Dra/Coordenadora do curso de agronomia do CESEP, Centro Superior de Ensino e Pesquisa \\ de Machado MG, Avenida Dr Athaide Pereira de Souza, S/N, Machado MG 37750-000
}

DOI: https://doi.org/10.51193/IJAER.2020.6506

\begin{abstract}
Coffee is one of the most consumed drinks worldwide, however the quality of the drink is associated with several extrinsic and intrinsic factors. A factor of interest to be evidenced in the coffee cultivars refers to the percentage of high sizes produced, obtaining a better quality coffee that is often conducive to export. The classification by sizes aims to analyze the homogeneity of the grains in relation to the shape and size. In view of the relevance of the theme, the objective of this study was to evaluate the processing of running spout coffee (RS) in different sizes in relation to quality, type, yield and economic viability. The research was carried out using coffee samples chosen at random in the sample file program of Armazém Sul Café in the city of Campos Gerais (MG). Twenty samples were selected, five of which were Arabica coffee processed naturally from the 2019/2020 harvest. The samples are composed of 300 grams of RS coffee. The treatments are: processing of RS coffee samples in a 13, 14, 15 and 16 sizes, where RS is the real sample, small flat beans are classified by size 13 and 14 and medium boring by sizes 15 and 16. After analysis of processing data in different sizes the coffee was subjected to the cup test. Regarding the number of defects, a reduction in size processing can be observed, however the treatment did not interfere with the quality of the drink. We conclude with the present study that the technical and economic viability of coffee processing in different size classifications is not due to the evaluated coffees not having expressive quality characteristics.
\end{abstract}

Keywords: Coffee profitability, Granulometry, Sensory analysis 
International Journal of Agriculture and Environmental Research

ISSN: 2455-6939

Volume: 06, Issue: 05 "September-October 2020"

\section{INTRODUCTION}

Coffee is one of the most consumed drinks worldwide. The quality of the coffee drink is associated with cultivation, harvest management and roasting practices (FERRÃO et al., 2019). According to Thomaziello (2014), the grains can be classified as imperfect and / or impure. In this context, flavor becomes its main characteristic, which is analyzed through intensity score analysis. The classification of cup in Brazil follows the guidelines of ordinance $\mathrm{n}^{\circ} .49$ of the Ministry of Agriculture, Livestock and Supply which follows the guidelines of the American Association of Specialty Coffees (SILVA et al., 2014).

The productivity of the coffee tree is related to several factors, among them the vigor of the plants, the architecture, the diameter of the stem, the resistance to pests and diseases, and yield stand out, the latter being provided through the varieties. In this context, the yield depends on factors, such as the point of maturity at the time of harvest, crop nutrition, leafing, climatic conditions of the year and the variety (BARTELEGA et al., 2018).

A factor of interest to be evidenced in coffee cultivars refers to the percentage of high sizes produced, obtaining a better quality coffee that is often conducive to export (BARTELEGA et al., 2018).

In this context, the classification by sizes aims to analyze the homogeneity of the grains in relation to the shape and size. The format analysis aims to classify the grains as flat and mocha, while in size the grains are classified according to the size of the sizes of the sizes that retain them. The classification by type is carried out according to the number of defects and impurities in the coffee; The analysis of intrinsic defects analyzes black, green, burnt grains, broken, brocaded, badly granulated or chochos and shells, as extrinsic defects, analyze foreign substances in coffee (coconut, sailor, peels, stick, stone and clods) (FERREIRA et al., 2010).

According to Thomaziello (2014) samples of 300 grams of coffee are analyzed by counting defective beans or present impurities. This classification follows the Official Classification Table (ARAÚJO FILHO, 2017), where each coffee cultivar corresponds to a larger number or less of defects found in the sample.

Given the relevance of the theme, the objective of this study was to evaluate the processing of coffee type "Bica Corrida" (BC) in different sizes in relation to quality, type, yield and economic viability.

\section{MATERIALS AND METHODS}

The research was carried out using coffee samples chosen at random in the sample file program of Armazém Sul Café in the city of Campos Gerais/MG. Twenty samples were selected, five of 
International Journal of Agriculture and Environmental Research

ISSN: 2455-6939

Volume: 06, Issue: 05 "September-October 2020"

which were Arabica coffee processed naturally from the 2019/2020 harvest. The selected coffee samples are representative of the reality of commercial coffee produced in the municipality. The samples are made up of 300 grams of BC type coffee. The treatments are: processing of BC coffee samples in size $13,14,15$ and 16 , where $\mathrm{BC}$ is the real sample, small flat beans are classified by size 13 and 14 and medium boring by sizes 15 and 16 .

The treatment of $\mathrm{BC}$ is a classification process without passing through sizes, with the aim of quantifying defects and utilization. In the sizes 13 to 16 the same RS coffee was classified, however separating the bottom of each one and quantifying the percentage of defects, according to the table of the Official Brazilian Classification - COB - (ARAÚJO, 2017).

Three hundred grams of each sample were weighed for selection in each treatment, where the number of defects and type according to the $\mathrm{COB}$ was evaluated, in which the number of defects according to the sizes is observed, through the analysis of impurities. The yield is evaluated according to each sample and each size, that is, generating a total of 20 samples of use. After this evaluation, the samples were submitted to a tasting according to methodology by type of coffee through cup tasting. With the result of the classifications and yields, the viability of processing these coffees by granulometric selection was evaluated. The data obtained were subjected to analysis of variance by the Scott-Knott test, at $5 \%$ probability in the SISVAR ${ }^{\circledR}$ statistical software (FERREIRA, 2014).

\section{RESULTS AND DISCUSSION}

It is known that the quality of the coffee drink is influenced by several extrinsic and intrinsic factors, however it is observed that the classification by coffee sizes is one of the criteria of coffee commercialization. According to Mendonça et al. (2005) the classification by sizes makes it possible to standardize the grains for the roasting process, since the unevenness provides an uneven roasting contributing to the product's burnt flavor.

In view of the relevance of the theme, it can be seen in the present study that, given the classification by number of defects (Table 1), the BC sample had a higher occurrence of defects, differing statistically from other size processing. It is observed that the number of defects has decreased in relation to sizes $13,14,15$ and 16 , this reduction justified due to the size of the size, since it selects the largest and smallest grains. The data presented corroborate the study by Nasser et al. (2001), which also identified a decrease in defects in relation to sizes larger than 13 . 
International Journal of Agriculture and Environmental Research

ISSN: 2455-6939

Volume: 06, Issue: 05 "September-October 2020"

Table 1: Classification by number of defects of coffee submitted to processing in different sizes

\begin{tabular}{cc}
\hline Sizes & Average \\
\hline BC & $165 \mathrm{~A}$ \\
13 & $119 \mathrm{~B}$ \\
14 & $80,4 \mathrm{C}$ \\
15 & $47,8 \mathrm{D}$ \\
16 & $28,6 \mathrm{E}$
\end{tabular}

*Different letters in the column, differ statistically by the Scott-Knott test at 5\% probability.

Regarding the classification by type of coffee (Table 2), it can be seen that size 13 and 14 did not show statistical differences between them.

Table 2: Classification by type of coffee submitted to processing in different sizes.

\begin{tabular}{rc}
\hline Sizes & Average \\
\hline BC & $7-5 \mathrm{~A}$ \\
13 & $6-25 \mathrm{~B}$ \\
14 & $6 \mathrm{~B}$ \\
15 & $5-5 \mathrm{C}$ \\
16 & $4-6 \mathrm{D}$
\end{tabular}

*Different letters in the column, differ statistically by the Scott-Knott test at 5\% probability.

The tasting aims to evaluate the characteristics of the taste and aroma of coffee. In this context, it can be seen that the number of sizes did not significantly influence the quality of the drink (Table 3). Such an analysis can be justified by the fact that BC is probably of low quality, generating nearby drinks without high scores. The present study corroborates Ferreira et al. (2010) research, where the authors did not identify a statistically significant difference between treatments for the evaluated size categories. The study by Franco Júnior et al. (2019), on the other hand, identified better grades in the Specialty Coffee Association Of America (SCAA) table in small size and small size. 
International Journal of Agriculture and Environmental Research

ISSN: 2455-6939

Volume: 06, Issue: 05 "September-October 2020"

Table 3: Classification by drink of coffee submitted to processing in different sizes.

\begin{tabular}{cl}
\hline Sizes & Average \\
\hline BC & Hard R \\
13 & Hard \\
14 & Hard RR \\
15 & Hard \\
16 & Hard R \\
\hline
\end{tabular}

*Different letters in the column, differ statistically by the Scott-Knott test at 5\% probability.

Regarding the yield (Table 4), the control of BC and size 13 there was no statistical difference, however, the coffees of sizes14 and 15 differed from the control work (BC).

Table 4: Yield in kg of a bag submitted to processing in different sizes.

\begin{tabular}{cl}
\hline Sizes & Average \\
\hline BC & $60,0 \mathrm{~A}$ \\
13 & $52,3 \mathrm{~A}$ \\
14 & $47,8 \mathrm{~B}$ \\
15 & $40,9 \mathrm{~B}$ \\
16 & $30,7 \mathrm{C}$ \\
\hline
\end{tabular}

*Different letters in the column, differ statistically by the Scott-Knott test at 5\% probability.

When analyzing the bottom of all sizes, it is considered that the one with the highest percentage in $\mathrm{kg}$ has the best coffee, since it has fewer defects and in contrast the beans are heavier. Therefore, there is a better type, drink and quality, even if it does not generate a great income. It is possible to observe through table 5 that sizes 13 and 14 did not show statistical difference and the best coffee consists of size 16 .

According to Bartelega et al. (2018), the yield of cultivars can be related to the thickness of the pericarp and seed size, when very small reduces the use.

When analyzing the bottom in $\mathrm{kg}$ (Table 5), it can be seen that sizes 16 and 15 differed statistically from sizes 13 and 14. The study by Coimbra et al. (2018) identified similar results for the bottom yield in kg processed in sizes 15 and 16. Souza and Moreira (2018) also identified a higher percentage of retention in the size $16 \mathrm{~m}$ in their research. 
International Journal of Agriculture and Environmental Research

ISSN: 2455-6939

Volume: 06, Issue: 05 "September-October 2020"

Table 5: Bottom in $\mathrm{kg}$ of a bag submitted to processing in different sizes.

\begin{tabular}{cc}
\hline Sizes & Average \\
\hline BC & $0,0 \mathrm{D}$ \\
13 & $7,7 \mathrm{C}$ \\
14 & $12,2 \mathrm{C}$ \\
15 & $19,1 \mathrm{~B}$ \\
16 & $29,3 \mathrm{~A}$ \\
\hline
\end{tabular}

*Different letters in the column, differ statistically by the Scott-Knott test at 5\% probability.

According to the Council of coffee exporters in brazil (Cecafé), on June 19, 2020, taking into account the amount of defects and drink, the prices for the size coffee bag 13 and 15 and 14 and 16 were as follows $\mathrm{R} \$ 472,00$ and $\mathrm{R} \$ 421,00$, respectively. In addition, the funds for each size are also sold at $\mathrm{R} \$ 150,00 ; \mathrm{R} \$ 170,00 ; \mathrm{R} \$ 230,00$ and $\mathrm{R} \$ 270,00$, following the order of sizes 13,14 , 15 and 16. Even though the gross value of size 13 is minimally higher than the $\mathrm{BC}$, it is not advantageous to the producer, as it requires more labor and specific machinery for this process (Table 6). According to Laviola et al. (2006) grains with a greater size, associated with other drink quality indicators, tend to have a higher market value, which was not identified in the present study.

Table 6: Gross price considering the yield and bottom of the different screens.

\begin{tabular}{lccccc}
\hline Sizes & Yield & Bottom & $\begin{array}{c}\text { Yield } \\
\text { value(RS) }\end{array}$ & Fund value & $\begin{array}{c}\text { Gross price } \\
(\mathrm{R} \$)\end{array}$ \\
\hline BC & 60 & -- & 421,00 & -- & 421,00 \\
13 & 52,3 & 7,7 & 411,00 & 18,00 & 430,00 \\
14 & 47,8 & 12,2 & 335,00 & 34,50 & 369,90 \\
15 & 40,9 & 19,1 & 321,00 & 73,00 & 394,00 \\
16 & 30,7 & 29,3 & 215,00 & 132,00 & 347,00 \\
\hline
\end{tabular}

*Different letters in the column, differ statistically by the Scott-Knott test at 5\% probability.

\section{CONCLUSION}

It is concluded that the processing of coffee in larger sizes reduced defects, improved the type according to $\mathrm{COB}$. However, it did not interfere with the quality of the drink and reduced the 
coffee yield in each size. Thus, it was not economically viable, probably because the evaluated coffees do not have expressive quality characteristics.

\section{REFERENCES}

ARAÚJO FILHO, José Ribeiro. O café, riqueza paulista. Boletim Paulista de Geografia, n. 23, p. 77-134, 2017.

BARTELEGA, L. et al. Rendimento do café cereja e classificação de peneiras de cultivares de café arábica. 2018.

COIMBRA, B. M. et al. Classificação por tamanho, formato e defeitos nos grãos de cultivares de café arábica. 2018. CBPC - Congresso Brasileiro de Pesquisas CafeeirasSBICafé. <http://www.sbicafe.ufv.br/bitstream/handle/123456789/11913/390_44-CBPC2018.pdf?sequence=1>. Acesso em 02 de outubro de 2020.

FERRÃO, R. G. et al. Qualidade do café arábica em diferentes altitudes no Espírito Santo. 2019. VI Simpósio de Pesquisa dos Cafés do Brasil. 2019. Disponível em https://biblioteca.incaper.es.gov.br/digital/bitstream/123456789/3699/1/altitude-cafe.pdf. Acesso em 20 de agosto de 2020.

FERREIRA, D. F. Programa Sisvar. exe: sistema de análise de variância. Lavras, Universidade Federal de Lavras, 2014.

FERREIRA, G. F. P; NOVAES, Q. Si; SOUZA, S E. Classificação por peneira e presença de defeitos em grãos de café (Coffea arabica $L_{\text {. }}$ ) processados por via seca e via úmida na região sudoeste da Bahia. 2010. CBPC - Congresso Brasileiro de Pesquisas Cafeeiras. 2010.Disponível em: http://www.sbicafe.ufv.br/handle/123456789/5069. Acesso em 30 de agosto de 2020

FRANCO JÚNIOR, et al. Qualidade do café arábica por diferentes granulometrias. Revista Ciência Agrícola, v. 17, n. 1, p. 31-35, 2019. Disponivel em https://www.seer.ufal.br/index.php/revistacienciaagricola/article/view/6495/5894. Acesso: $21 / 10 / 2020$

LAVIOLA, B. G. et al. Influência da adubação na formação de grãos mocas e no tamanho de grãos de café (Coffea arabica L.). Coffee science, v. 1, n. 1, p. 36-42, 2006.

MENDONÇA, L. M. V. L et al. Classificação por peneira de grãos de Coffea arabica L. avaliada por meio de análise multivariada. 2005. Embrapa café. Disponível em: 
http://www.sapc.embrapa.br/arquivos/consorcio/spcb_anais/simposio4/p249.pdf. Acesso em 29 de setembro de 2020.

NASSER, P. P. et al. Influência da separação de café (Coffea arabica L.) de acordo com o tamanho sobre o espectro de coloração dos grãos. 2001. II Simpósio de Pesquisas de Café do Brasil. 2001.

SILVA, P. A. et al. Quality assessment of coffee grown in Campos Gerais, Minas Gerais State, Brazil. Acta Scientiarum. Technology, v. 36, n. 4, p. 739-744, 2014.

SOUZA, R.C; MOREIRA, V.D. Influência do sombreamento do café agroecológico nas características sensoriais e fisico-químicas da bebida. 2018. 53f. Trabalho de Conclusão. Programa de Ciência e Tecnologia de Alimentos. Instituto Federal de Educação Ciência e Tecnologia do Sudeste de Minas Gerais. Rio Pomba,2018.

THOMAZIELLO, R. A. A classificação do café. Revista cafeicultura, 2014. Disponível em: https://revistacafeicultura.com.br/?mat=55115>. Acesso em: 19 jun. 2020. 